\title{
Formulasi dan Uji Sifat Fisik Sediaan Lulur Krim dari Ekstrak Etanol Daun Sirsak (Annona muricata L.) serta Penentuan Aktivitas Antioksidannya
}

(Formulation and evaluation of the phyical characteristics of scrub cream from ethanolic extract of soursop (Annona muricata L.) leaves and determination of its antioxidant activity)

\section{Zainur Rahman Hakim*, Dewi Meliana \& Pri Iswati Utami}

Fakultas Farmasi Universitas Muhammadiyah Purwokerto, Jl. KH. Ahmad Dahlan, Dusun III, Dukuhwaluh, Kec.

\begin{abstract}
The ethanolic extract of soursop leaves (Annona muricata L.) is reported as an antioxidant agent with an $I_{50}$ value of $14.48 \mu \mathrm{g} / \mathrm{mL}$. This research aimed to examine physical characteristics and investigate the antioxidant activity of the ethanolic extract of soursop leaves in a scrub cream. Soursop leaves powder was extracted with $70 \%$ ethanol and formulated as scrub cream at the concentration of $1.4 \%, 2.8 \%$, and $4.2 \%$, then evaluated for physical characteristics. The antioxidant activity was evaluated using DPPH (1.1-diphenyl-2 picrylhydrazyl) method. The result showed that the scrub cream at all concentrations tested fulfilled all physical characteristics required for good topical preparations. These included organoleptic, homogeneity, viscosity, $\mathrm{pH}$, spreadability, and adhesion. The $\mathrm{IC}_{50}$ value of the scrub cream at the concentration of $1.4 \%, 2.8 \%$, and $4.2 \%$ were 30.72 , 26.82 , and $24.03 \mu \mathrm{g} / \mathrm{mL}$, respectively. The $\mathrm{IC}_{50}$ values indicated that the scrub creams exhibit radical scavenging activities which categorized as strong activity antioxidants.
\end{abstract}

Keywords: antioxidants; Annona muricata L; soursop leaves; scrub cream; DPPH.

ABSTRAK: Ekstrak etanol daun sirsak (Annona muricata L.) dilaporkan memiliki aktivitas antioksidan dengan nilai konsentrasi hambat $50\left(\mathrm{IC}_{50}\right)$ sebesar $14,48 \mathrm{\mu g} / \mathrm{mL}$. Penelitian ini bertujuan untuk mengetahui sifat fisik dan aktivitas antioksidan dari lulur krim ekstrak etanol daun sirsak. Serbuk kering daun sirsak diekstraksi dengan etanol $70 \%$ kemudian dibuat formula lulur krim dengan konsentrasi 1,4\%, 2,8\%, dan 4,2\% lalu dilakukan uji sifat fisiknya. Aktivitas antioksidan ditentukan dengan metode DPPH (1,1-difenil-2-pikrilhidrazil). Hasil penelitian menunjukkan bahwa lulur krim ekstrak daun sirsak pada semua konsentrasi memenuhi semua persyaratan uji sifat fisik sediaan topikal yang baik. Hal ini meliputi organoleptis, homogenitas, viskositas, $\mathrm{pH}$, daya sebar dan daya lekat. Nilai IC $C_{50}$ lulur krim ekstrak etanol daun sirsak dengan konsentrasi 1,4\%; 2,8\%; dan 4,2\% adalah 30,72; 26,82; dan $24,03 \mu \mathrm{g} / \mathrm{mL}$. Hal ini menunjukkan bahwa sediaan lulur krim ekstrak daun sirsak memiliki aktivitas antioksidan atau penangkapan radikal bebas dengan kategori sangat aktif.

Kata kunci: antioksidan; Annona muricata L; daun sirsak; lulur krim; DPPH.

\section{Pendahuluan}

Seiring dengan berkembangnya ilmu pengetahuan dan teknologi, kebutuhan terhadap kecantikan menjadi prioritas utama dalam menunjang penampilan sehari-hari, terutama bagi para wanita. Hal yang berhubungan dengan kecantikan tersebut salah satunya adalah kesehatan kulit. Setiap hari kulit tubuh mengalami regenerasi sehingga beberapa sel kulit mati yang menumpuk menyebabkan kulit terlihat kusam. Selain itu, efek dari polusi udara, pendingin ruangan, dan stress juga dapat menyebabkan kulit kering, timbul flek-flek hitam, dan bahkan mempercepat proses penuaan dini. Beberapa cara untuk mengurangi kerusakan kulit dari radikal bebas yaitu dengan pemakaian tabir surya, obat topikal vitamin A atau turunannya, obat topikal yang mengandung antioksidan, serta mengkonsumsi antioksidan yang terdapat pada makanan maupun berupa suplemen [1]. Pemakaian antioksidan sintetis seperti asam betahidroksi (BHA) dan butil hidroksitoluen (BHT) dilaporkan menyebabkan masalah serius seperti adanya kerusakan hati [2], sehingga perlu dicari alternatif lain dari bahan alam sebagai sumber antioksidan.

Salah satu tanaman yang

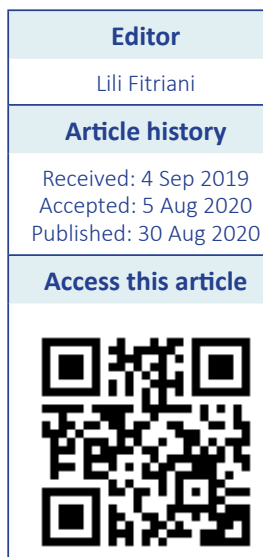




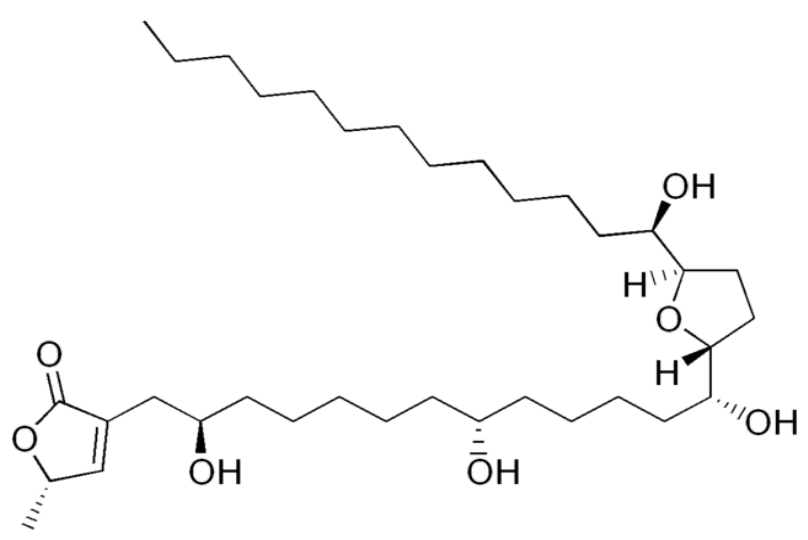

Gambar 1. Sruktur acetogenin dari daun sirsak (Annona muricata L.)

memiliki efek antioksidan adalah daun sirsak (Annona muricata L.) yang memiliki aktivitas antioksidan yang sangat kuat dengan nilai $\mathrm{IC}_{50} 18 \mu \mathrm{g} / \mathrm{mL}$ [3]. Penelitian sebelumnya menunjukkan bahwa kandungan fenolik dari ekstrak etanol daun sirsak dapat digunakan untuk melindungi tubuh dari patogen dan meningkatkan peran antioksidan [4].

Daun sirsak mengandung acetogenins (Gambar 1) yang merupakan senyawa penting yang paling banyak terdapat di dalam daun dan batang sirsak. Senyawa ini berkhasiat sebagai antioksidan dan antiinflamasi terhadap sel-sel abnormal pada tubuh [5]. Daun dan batang sirsak juga memiliki aktivitas sitotoksik terhadap sel kanker yang pertumbuhannya sangat cepat di dalam jaringan tubuh [6]. Walaupun sifatnya sitotoksik yaitu bersifat racun terhadap sel, namun acetogenin relatif tidak menyerang sel normal dan hanya menyerang sel kanker secara spesifik [7].

Sampai saat ini belum ada penelitian tentang pemanfaatan daun sirsak yang dibuat dalam bentuk sediaan lulur krim. Lulur krim merupakan sediaan berupa krim yang mengandung butiran-butiran kasar di dalamnya [8]. Berdasarkan uraian di atas penulis melakukan penelitian tentang formulasi lulur krim ekstrak etanol daun sirsak (Annona muricata L.) dan menguji aktivitas antioksidannya secara in vitro.

\section{Metode Penelitian}

Bahan

Daun sirsak (Annona muricata L.) diperoleh dari Desa Sikampuh, Kecamatan Kroya, Kabupaten Cilacap. Bahan lain yang digunakan adalah 1,1-difenil-2-pikrilhidrazil (DPPH) (SigmaChem.co, Jerman), vitamin C, etanol $70 \%$, metanol pro-analisis (Merck, Jerman), lemak kakao, minyak zaitun, setil alkohol, asam stearat, propil paraben, propilenglikol, metil paraben, trietanolamin (TEA) dan air suling (BrataChem, Indonesia), tepung beras (Rosebrand, Indonesia), susu bubuk, dan madu.

\section{Penyiapan Ekstrak Tanaman}

Sebanyak 300 g serbuk simplisia daun sirsak diekstraksi dengan $3000 \mathrm{~mL}$ pelarut etanol 70\% dengan metode remaserasi selama $3 \times 24$ jam [9]. Maserat yang diperoleh lalu diuapkan dengan vacuum rotary evaporator (IKA, Jerman) dan dilanjutkan di dalam cawan porselin di atas waterbath (Memmert GmbH.co, Jerman) sampai diperoleh massa kental.

\section{Pembuatan Lulur Krim}

Formula dasar yang digunakan pada pembuatan lulur krim ekstrak etanol daun sirsak terdiri atas fase air dan fase minyak [10]. Fase minyak terdiri atas lemak kakao $1,4 \%$, minyak zaitun $10 \%$, setil alkohol $1 \%$, asam stearat $3 \%$, propil paraben $0,1 \%$ dan fase air terdiri dari propilen glikol 10\%, metil paraben $0,1 \%$, dan TEA 1,9\%. Fase minyak dan fase air dilarutkan dan dipanaskan masingmasing pada suhu $70^{\circ} \mathrm{C}$. Kemudian keduanya dicampurkan dengan cara fase minyak dituang ke dalam fase air dengan kecepatan lambat. Setelah terbentuk lulur krim, tepung beras, susu bubuk, madu dan ekstrak etanol daun sirsak. Lulur dibuat dengan empat formula, yaitu F1, F2, dan F3 yang mengandung ekstrak dengan konsentrasi 1,4; 2,8; dan $4,2 \%$, serta formula kontrol yang tidak mengandung ekstrak (Tabel 1). Lulur krim yang sudah diformulasi lalu dipindahkan ke dalam wadah pot untuk disimpan [11].

\section{Uji Sifat Fisik Lulur Krim}

\section{Uji Organoleptis}

Uji organoleptis dilakukan dengan mengamati perubahan bentuk, warna, dan bau dari sediaan lulur krim yang mengandung ekstrak etanol daun sirsak [12].

\section{Uji Homogenitas}

Sebanyak 0,5 g lulur krim diambil dari masing-masing formula, dioleskan menggunakan spatula pada pelat kaca. Saat diraba dan digosokkan, massa lulur krim harus menunjukkan susunan homogen pada kaca [12].

\section{Uji Derajat Keasaman (pH)}

Pengukuran $\mathrm{pH}$ dilakukan dengan menggunakan stik indikator $\mathrm{pH}$ (Merck, USA) yang dicelupkan ke dalam sediaan lulur krim, kemudian didiamkan sesaat. Perubahan warna diamati dan nilai $\mathrm{pH}$ dicatat [12]. 
Tabel 1. Formulasi lulur krim ekstrak etanol daun sirsak

\begin{tabular}{lcccc}
\hline \multirow{2}{*}{ Bahan } & \multicolumn{4}{c}{ Jumlah Bahan } \\
\cline { 2 - 5 } & F1 (1,4\% ekstrak) & F2 (2,8\% ekstrak) & F3 (4,2\% ekstrak) & Kontrol negatif \\
\hline Ekstrak daun sirsak (g) & 1,4 & 2,8 & 4,2 & - \\
Lemak kakao (g) & 1,4 & 1,4 & 1,4 & 1,4 \\
Minyak zaitun (g) & 10 & 10 & 10 & 10 \\
Setil alkohol (g) & 1 & 1 & 1 & 1 \\
Asam stearat (g) & 3 & 3 & 3 & 3 \\
Propil Paraben (g) & 0,1 & 0,1 & 0,1 & 0,1 \\
Propilenglikol (g) & 10 & 10 & 10 & 10 \\
Metil paraben (g) & 0,1 & 0,1 & 0,1 & 0,1 \\
Trietanolamin (g) & 1,9 & 1,9 & 1,9 & 1,9 \\
Tepung beras (g) & 4 & 4 & 4 & 4 \\
Susu bubuk (g) & 1 & 1 & 1 & 1 \\
Madu (g) & 2,5 & 2,5 & 2,5 & 2,5 \\
Air suling (mL) & ad 100 & ad 100 & ad 100 & ad 100 \\
\hline
\end{tabular}

\section{Uji Viskositas}

Sediaan lulur krim diukur viskositasnya menggunakan alat Viscometer (Brookfield LV, USA). Sampel dimasukkan ke dalam wadah, kemudian spindle dimasukkan hingga tanda batas. Klep pengaman dilepaskan dan rotor dihidupkan, dibiarkan selama beberapa waktu hingga didapat angka yang stabil [12].

\section{Uji Daya Sebar}

Sebanyak 0,5 g lulur krim diletakkan di tengah kaca bulat berskala, di atas lulur krim diletakkan kaca bulat lain dan dibiarkan selama 1 menit. Diameter lulur krim yang menyebar dicatat. Beban seberat $50 \mathrm{~g}$ diletakkan di atas kaca bulat dan didiamkan selama 1 menit lalu diukur kembali diameter lulur krim yang menyebar. Eksperimen dilakukan berulang kali dengan interval waktu yang sama sampai didapat diameter sebar yang konstan [13].

\section{Uji Daya Lekat}

sebanyak 0,2 g lulur krim dioleskan pada sebuah pelat kaca. Pelat berikutnya ditempelkan ke pelat yang lain hingga keduanya menyatu, dan ditekan dengan beban seberat $1 \mathrm{~kg}$ selama 5 menit, setelah itu beban dilepaskan. Durasi hingga kedua pelat saling lepas dicatat [12].

\section{Uji Aktivitas Antioksidan}

Pembuatan Larutan 1,1-difenil-2-pikerilbidrazil (DPPH)

Pembuatan larutan DPPH dilakukan dengan menimbang $10 \mathrm{mg}$ serbuk DPPH (BM 394,32) yang dilarutkan dalam metanol pro-analisis kemudian dimasukkan ke dalam labu ukur $250 \mathrm{~mL}$, volumenya dicukupkan dengan metanol pro-analisis sampai tanda batas sehingga diperoleh larutan DPPH dengan konsentrasi $0,1 \mathrm{mM}$.

\section{Penetapan Panjang Gelombang Maksimum DPPH}

Penetapan panjang gelombang maksimum dilakukan dengan membuat larutan DPPH 0,1 mM sebanyak $2 \mathrm{~mL}$ dimasukkan ke dalam tabung reaksi lalu ditambahkan metanol pro-analisis sebanyak $2 \mathrm{~mL}$, dikocok dengan vortex (IKA, Jerman) hingga homogen lalu dituang ke dalam kuvet dan diukur serapannya pada panjang gelombang 400-800 nm dengan menggunakan spektrofotometer UVVis (Shimadzu 1800, Jepang).

\section{Pembuatan Larutan Induk dan Seri Konsentrasi Ekstrak}

Ekstrak etanol daun sirsak ditimbang sebanyak 0,01 g kemudian dilarutkan dalam metanol pro-analisis dalam labu ukur $100 \mathrm{~mL}$ untuk membuat larutan induk $100 \mu \mathrm{g} /$ mL. Larutan induk $100 \mu \mathrm{g} / \mathrm{mL}$ tersebut kemudian diambil sebanyak 50,100, 150, 200, dan $250 \mu \mathrm{L}$ menggunakan pipet mikro (ResearchPlus, Singapura) dan diencerkan dengan 
metanol hingga volume $10 \mathrm{~mL}$, sehingga terbentuk larutan dengan konsentrasi 0,$5 ; 1 ; 1,5 ; 2,0 ;$ dan $2,5 \mu \mathrm{g} / \mathrm{mL}$.

\section{Penetapan Konsentasi Hambat 50 (IC 50 )}

Sebanyak 2,0 $\mathrm{mL}$ masing-masing larutan ekstrak dengan konsentrasi 0,$5 ; 1 ; 1,5 ; 2,0 ;$ dan $2,5 \mu \mathrm{g} / \mathrm{mL}$ ditambahkan 2,0 $\mathrm{mL}$ larutan DPPH 0,1 mM kemudian diinkubasi pada suhu $37^{\circ} \mathrm{C}$ selama 30 menit di dalam tempat gelap. Serapan kemudian diukur pada panjang gelombang maksimum [14]. Sebanyak 2,0 mL larutan pembanding vitamin $\mathrm{C}$ dengan konsentrasi 0,$5 ; 1 ; 1,5$; 2,0; dan 2,5 $\mu \mathrm{g} / \mathrm{mL}$ ditambahkan 2,0 $\mathrm{mL}$ larutan $\mathrm{DPPH}$ $0,1 \mathrm{mM}$ kemudian diinkubasi pada suhu $37^{\circ} \mathrm{C}$ selama 30 menit di dalam tempat gelap. Serapan kemudian diukur pada panjang gelombang maksimum. Hasil serapan larutan uji dibandingkan dengan hasil serapan vitamin C (Brataco, Indonesia) sebagai kontrol positif [15].

\section{Pengujian Aktivitas Penangkap Radikal Bebas}

Sebanyak $10 \mathrm{mg}$ sediaan lulur krim dilarutkan dalam metanol pro-analisis dalam labu ukur $10 \mathrm{~mL}$, kemudian diaduk hingga homogen untuk membuat larutan induk $1000 \mu \mathrm{g} / \mathrm{mL}$. Setelah itu dibuat beberapa seri konsentrasi 0,$5 ; 1 ; 1,5 ; 2,0 ;$ dan $2,5 \mu \mathrm{g} / \mathrm{mL}$ dengan mengambil sebanyak 50, 100, 150, 200, dan $250 \mu \mathrm{L}$ dengan (ResearchPlus, Singapura) dan dicukupkan volumenya hingga $10 \mathrm{~mL}$. Masing-masing seri konsentrasi diambil sebanyak $2 \mathrm{~mL}$ dan ditambahkan dengan $2 \mathrm{~mL}$ DPPH 0,1 mM dalam metanol, dihomogenkan, lalu disimpan di ruangan gelap selama 30 menit. Selanjutnya absorbansi larutan diukur pada panjang gelombang maksimum menggunakan spektrofotometer UV-Vis (Shimadzu, Jepang). Aktivitas antioksidan dinyatakan secara kuantitatif dengan $\mathrm{IC}_{50}$ yaitu konsentrasi larutan uji yang memberikan peredaman DPPH sebesar 50\%. Aktivitas antioksidan dapat diketahui dengan menghitung daya penghambatannya (\%) terhadap oksidasi DPPH sesuai perhitungan rumus yaitu:

\section{$\%$ Penghambatan $=\frac{\text { Abs kontrol }- \text { Abs sampel }}{\text { Abs kontrol }} \times 100 \%$}

Keterangan:

Abs kontrol $=$ Nilai Absorbansi DPPH

Abs sampel $=$ Nilai Absorbansi dari larutan DPPH yang ditambahkan

\section{Analisis Data}

Data uji sifat fisik dan aktivitas antioksidan dinyatakan sebagai rerata $\pm \mathrm{SD}$. Data dianalisis dengan metode one-way ANOVA dengan bantuan perangkat lunak SPSS 16 for Windows (IBM.Inc, USA) dengan tingkat kepercayaan 95\%.

\section{Hasil dan Diskusi}

Hasil identifikasi tumbuhan menunjukkan bahwa daun yang digunakan dalam penelitian adalah berasal dari tanaman sirsak (Annona muricata L.). Proses ekstraksi dilakukan dengan remaserasi pelarut etanol 70\% selama tiga kali pengulangan selama 72 jam (3x24 jam) [9]. Proses remaserasi juga dibantu dengan proses pengadukan pada temperatur ruang agar pelarut tidak cepat jenuh dan kandungan kimia dapat tersari maksimal [16]. Ekstrak etanol daun sirsak yang diperoleh sebanyak 59,82 g dengan rendemen sebesar 19,94\%. Hal ini berbeda dengan penelitian sebelumnya dikarenakan perbedaan tempat tumbuh dan metode penyarian [17]. Pelarut etanol 70\% dipilih untuk penyarian simplisia karena sifatnya yang mampu menarik hampir semua senyawa baik yang bersifat polar, semi polar dan nonpolar serta kemampuan pelarut ini dalam mengendapkan protein enzim tanaman yang dapat merusak senyawa aktif [17].

Lulur krim yang dibuat berisi serbuk kasar yang dimaksudkan untuk mengangkat kotoran dan sel-sel kulit mati sekaligus melembabkan kulit. Lulur krim diformulasi berdasarkan komposisi lulur krim dari penelitian sebelumnya [11] dengan sedikit modifikasi (Tabel 1). Aspek yang diamati dalam pemeriksaan organoleptik meliputi bentuk, warna, dan bau dari sediaan lulur krim. Pemeriksaan organoleptik dilakukan dengan pengamatan langsung tanpa menggunakan alat bantu yaitu langsung dioleskan pada kulit lengan. Hasil pengamatan menunjukkan bahwa lulur krim ekstrak etanol daun sirsak mempunyai karakteristik warna, bau, dan tekstur yang baik sebagai sediaan lulur krim (Tabel 2).

Pengujian homogenitas lulur krim dilakukan untuk mengetahui apakah zat aktif tercampur secara homogen dengan basis dan bahan tambahan lainnya pada saat proses pembuatan lulur krim. Hasil pengujian homogenitas menunjukkan bahwa lulur krim dengan konsentrasi ekstrak 1,4; 2,8; dan 4,2\% tidak menggumpal saat diraba,

Tabel 2. Hasil pengamatan organoleptik lulur krim

\begin{tabular}{cccc}
\hline Formula & Bentuk & Warna & Bau \\
\hline F1 (1,4\% ekstrak) & Semi padat & Hijau kecoklatan & Khas \\
F2 $(2,8 \%$ ekstrak $)$ & Semi padat & Hijau kecoklatan & Khas \\
F3 (4,2\% ekstrak) & Semi padat & Hijau kehitaman & Khas \\
Kontrol negatif & Semi padat & Putih & Khas \\
Kontrol positif & Agak kental & Putih & Khas \\
\hline
\end{tabular}


Tabel 3. Hasil uji sifat fisik lulur krim

\begin{tabular}{cc} 
Formula & Derajat asam (pH) \\
\hline F1 (1,4\% ekstrak) & 7,1 \\
F2 (2,8\% ekstrak) & 7,2 \\
F3 (4,2\% ekstrak) & 7,4 \\
Kontrol negatif & 8 \\
\hline
\end{tabular}

sehingga sediaan lulur krim yang dibuat telah tercampur secara homogen dan memiliki tekstur yang rata seperti terlihat pada.

Pengujian derajat keasaman $(\mathrm{pH})$ dilakukan untuk menyesuaikan $\mathrm{pH}$ sediaan yang dibuat dengan $\mathrm{pH}$ kulit manusia sehingga tidak mengiritasi kulit. Hasil pengukuran pH sediaan (Tabel 3) menunjukkan bahwa lulur krim ekstrak daun sirsak memiliki $\mathrm{pH}$ rata-rata 7 yang sesuai dengan syarat mutu $\mathrm{pH}$ produk krim pelembab kulit menurut Standar Nasional Indonesia (SNI) Nomor 164399-1996 yaitu berkisar antara 4,5-8 [18]. Oleh karena itu, sediaan lulur krim ekstrak daun sirsak relatif aman

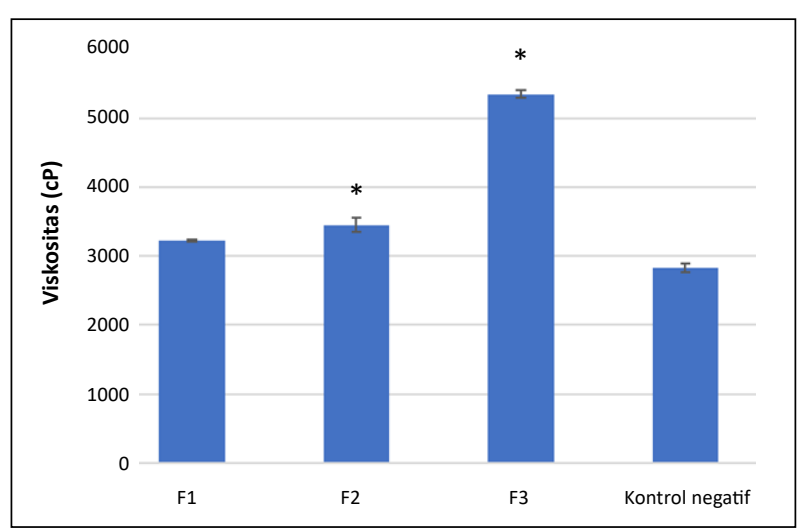

Gambar 2. Viskositas lulur krim daun sirsak (*Berbeda signifikan $(\mathrm{p}<0,05)$ dengan kontrol negatif).

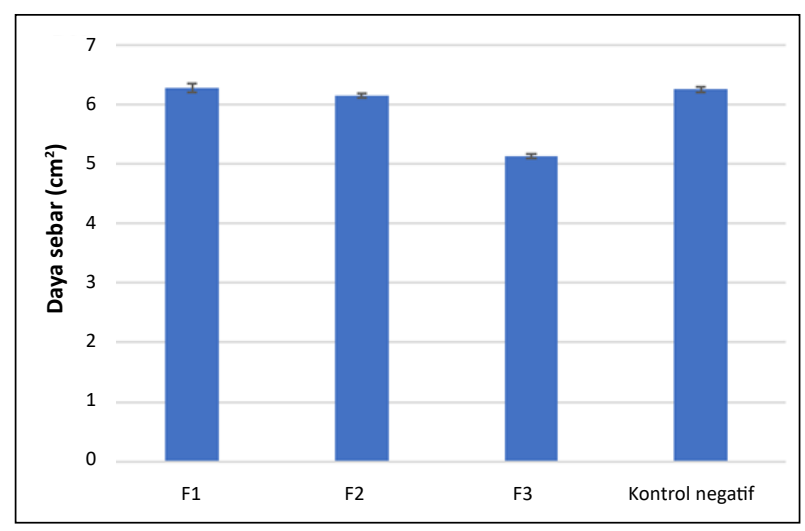

Gambar 3. Daya sebar lulur krim daun sirsak

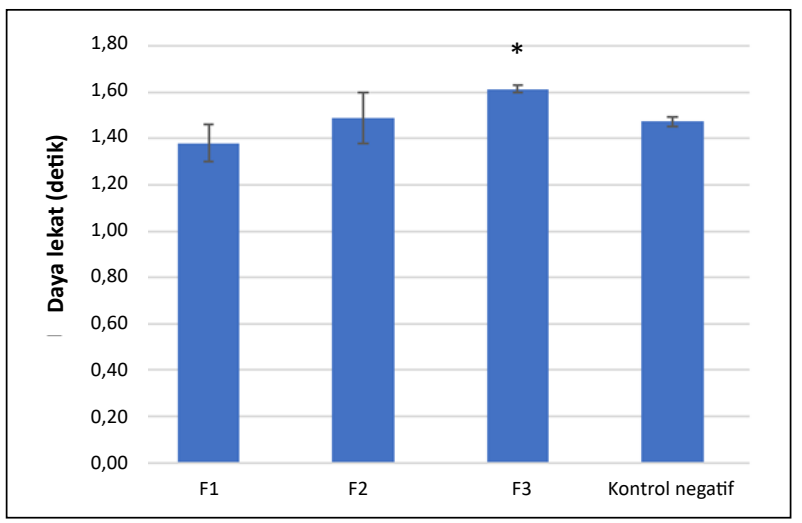

Gambar 4. Daya lekat lulur krim daun sirsak (*Berbeda signifikan $(\mathrm{p}<0,05)$ dengan kontrol negatif).

untuk digunakan karena. Selain itu, nilai $\mathrm{pH} 7$ masih tidak berbeda jauh dengan rentang $\mathrm{pH}$ fisiologis kulit yaitu 4,56,5. Aspek derajat keasaman penting untuk diperhatikan karena nilai $\mathrm{pH}$ yang lebih tinggi dari $\mathrm{pH}$ fisiologis kulit dapat menyebabkan kulit kering sedangkan $\mathrm{pH}$ yang lebih rendah dapat menimbulkan iritasi pada kulit [19].

Uji viskositas bertujuan untuk mengetahui tingkat kekentalan dari sediaan lulur krim. Hasil pengukuran rata-rata viskositas (Tabel 3) menunjukkan bahwa sediaan lulur krim ekstrak daun sirsak memiliki viskositas baik dan memenuhi syarat yang ditetapkan SNI 16-4399-1996, yaitu dalam kisaran nilai antara 2.000-50.000 cP [18]. Hasil ini menunjukkan bahwa semakin tinggi konsentrasi ekstrak daun sirsak yang digunakan dalam sediaan maka semakin tinggi viskositas. Formula F1 dengan kandungan ekstrak 1,4\% memiliki nilai viskositas berkisar $2746 \mathrm{cP}$, namun meningkat drastis menjadi $4083 \mathrm{cP}$ setelah konsentrasi ekstrak dinaikkan menjadi 2 kali lipat. Hal ini disebabkan karena ekstrak memang memilki kandungan yang lebih kental sifat alirnya [20]. Berdasarkan hasil analisis statistik menggunakan one-way ANOVA diperoleh hasil nilai

Tabel 4. Hasil nilai konsentrasi hambat $\mathrm{IC}_{50}$

\begin{tabular}{lc}
\hline \multicolumn{1}{c}{ Larutan Uji } & Rata - rata $\mathbf{~ C}_{\mathbf{5 0}}$ (ppm) \\
\hline F1 (1,4\% ekstrak) & 30,72 \\
F2 (2,8\% ekstrak) & 26,82 \\
F3 (4,2\% ekstrak) & $24,03 *$ \\
Kontrol negatif & 353,15 \\
Kontrol positif & 119,01 \\
Ekstrak daun sirsak & 14,48 \\
Vitamin C & 6,75 \\
\hline *F3 berbeda signifikan $p<0,05$ &
\end{tabular}




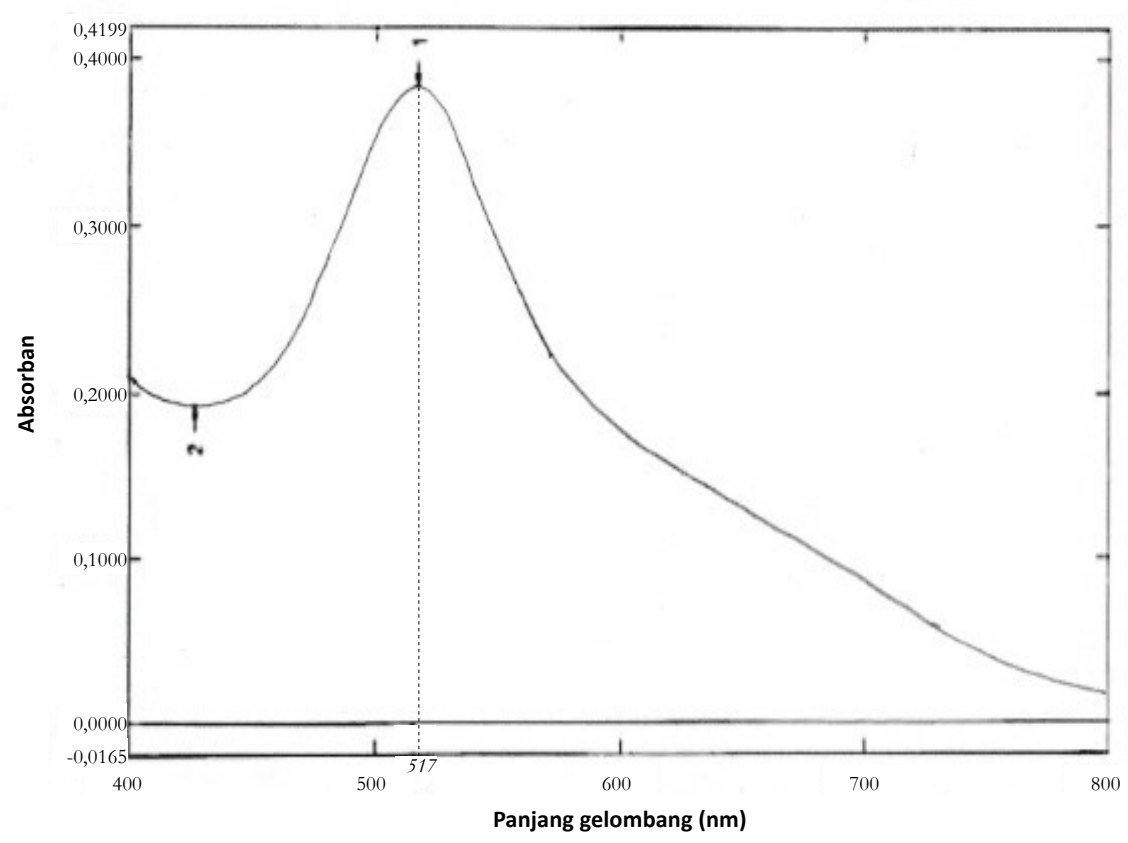

Gambar 5. Panjang gelombang maksimum $517 \mathrm{~nm}$ larutan DPPH 0,1 mM

$\mathrm{p}<0,05$ yang artinya terdapat perbedaan antara ketiga formula. Uji lanjutan Tukey's honestly significant difference juga menunjukkan perbedaan signifikan nilai viskositas ketiga formula $(\mathrm{p}<0,05)$, namun jika dibandingkan antara formula F2 dan F3 maka tidak terdapat perbedaan viskositas yang signifikan $(\mathrm{p}>0,05)$ yang disajikan pada Gambar 2 .

Uji daya sebar bertujuan untuk menggambarkan kemampuan penyebaran lulur krim setelah dioleskan pada kulit. Hasil pengukuran daya sebar lulur krim ekstrak daun sirsak dapat dilihat pada Tabel 3. Berdasarkan hasil tersebut, diketahui bahwa lulur krim dengan konsentrasi ekstrak 1,4; 2,8; dan 4,2\% memenuhi persyaratan sediaan topikal yang baik memiliki nilai daya sebar berkisar 5-7 $\mathrm{cm}$ [21]. Daya sebar yang baik diperoleh jika sediaan lulur krim mampu mempertahankan air dengan stabil, sehingga bertambahnya ekstrak tidak terlalu berpengaruh terhadap

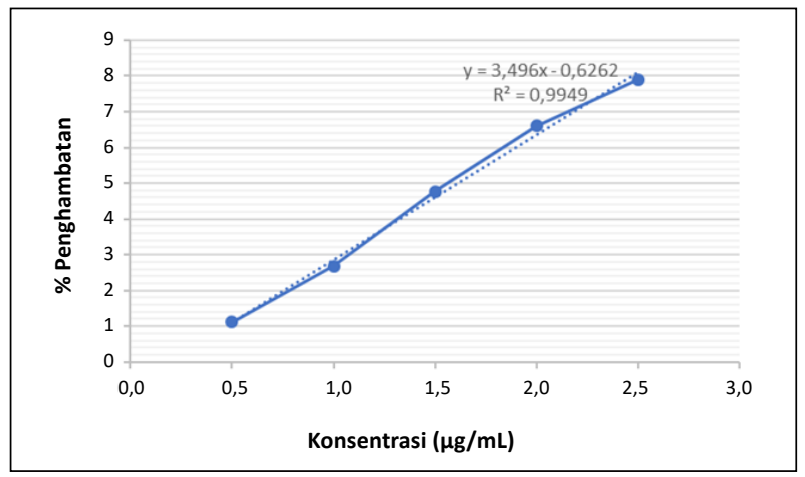

Gambar 6. Aktivitas antioksidan ekstrak etanol daun sirsak daya sebar [22]. Uji one-way ANOVA menunjukkan tidak ada perbedaan yang bermakna antara masing-masing formula $(p>0,05)$ yang dapat dilihat pada Gambar 3 .

Uji daya lekat bertujuan untuk mengetahui seberapa lama waktu yang dibutuhkan oleh sediaan lulur krim untuk melekat pada permukaan kulit. Hasil uji menunjukkan daya lekat lulur krim ekstrak etanol daun sirsak sesuai dengan persyaratan seperti dilihat pada Tabel 3, dimana sediaan krim bertipe minyak dalam air (M/A) memiliki kandungan air lebih banyak sehingga lulur krim memiliki daya lekat yang singkat [23]. Hasil analisis menggunakan one-way ANOVA menunjukkan bahwa terdapat perbedaan antara ketiga formula $(\mathrm{p}<0,05)$. Uji analisis lanjutan dengan Tukey's HSD juga menunjukkan perbedaan signifikan antara formula F3 dengan formula yang lain seperti yang ditunjukkan oleh Gambar 4.

Hasil pengukuran panjang gelombang maksimum DPPH 0,1 mM menunjukkan angka $517 \mathrm{~nm}$ dengan absorbansi sebesar 0,3833 (Gambar 5). Sehingga

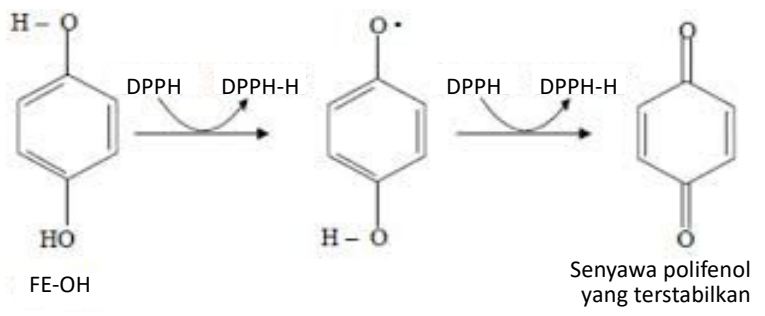

Gambar 7. Aksi peredaman DPPH oleh polifenol [25] 
selanjutnya pengukuran aktivitas antioksidan dilakukan pada panjang gelombang maksimum $517 \mathrm{~nm}$ pada seluruh sampel.

Setelah itu dilakukan perhitungan persen penghambatan (\% inhibisi) dan nilai konsentrasi $\mathrm{IC}_{50}$ pada ekstrak etanol daun sirsak. Persen peghambatan (\% inhibisi) adalah kemampuan suatu bahan untuk menghambat radikal bebas, sedangkan $\mathrm{IC}_{50}$ merupakan konsentrasi sampel yang mampu mereduksi aktivitas DPPH sebesar 50\%. Semakin rendah nilainya maka semakin besar kemampuannya sebagai antioksidan. Hasil pengujian $\mathrm{IC}_{50}$ ekstrak ekstrak etanol daun sirsak pada penelitian ini menunjukkan nilai $14,48 \mu \mathrm{g} / \mathrm{mL}$ yang menunjukkan aktivitas antioksidan yang lebih kuat dibandingkan dengan penelitian sebelumnya, yaitu dengan nilai $\mathrm{IC}_{50}$ sebesar $18 \mu \mathrm{g} / \mathrm{mL}$ [3]. Perbedaan ini dapat terjadi akibat perbedaan lokasi tumbuh tanaman yang mempengaruhi jumlah kandungan kimianya. Senyawa acetogenin yang terkandung di dalam ekstrak mempunyai banyak gugus fenol (polifenol) yang berkhasiat sebagai antioksidan pengikat radikal bebas DPPH [24] yang diilustrasikan pada Gambar 7 [25].

Evaluasi aktivitas antioksidan lulur krim menunjukkan bahwa ekstrak daun sirsak $1,4 \%$ dan 2,8\% memiliki nilai $\mathrm{IC}_{50} 30,72$ dan $26,82 \mu \mathrm{g} / \mathrm{mL}$, yang berarti bahwa daya penangkapan radikal bebasnya adalah aktif. Lulur krim dengan konsentrasi ekstrak 4,2\% mempunyai daya penangkapan radikal bebas yang sangat aktif dengan nilai $\mathrm{IC}_{50}$ sebesar 24,03 $\mu \mathrm{g} / \mathrm{mL}$ (Tabel 4). Data ini menunjukkan bahwa semakin tinggi konsentrasi ekstrak daun sirsak maka daya penangkapan radikal bebasnya semakin aktif [26].

\section{Kesimpulan}

Formulasi lulur krim ekstrak etanol daun sirsak menghasilkan sediaan yang baik secara organoleptis, homogenitas, viskositas, $\mathrm{pH}$, daya sebar dan daya lekat. Aktivitas penangkapan radikal bebas lulur krim ekstrak dengan konsentrasi $1,4 \% ; 2,8 \%$; dan $4,2 \%$ adalah 30,72 ; 26,82; dan 24,03 $\mu \mathrm{g} / \mathrm{mL}$, secara berturut-turut. Formula lulur krim ekstrak etanol daun sirsak memiliki aktivitas antioksidan dengan aksi penangkapan radikal bebas yang masuk dalam kategori sangat aktif.

\section{Referensi}

[1] Baumann L, Alleman IB. Antioxidants. In: Cosmetic Dermatology: Principles and Practice. 2nd ed. New York: McGraw-Hill Professional, New York; 2009. p. 292-311.

[2] Rahman N, Bahriul P, Diah A. Uji Aktivitas Antioksidan Ekstrak Daun Salam (Syzygium polyanthum) dengan Menggunakan 1,1-Difenil-2Pikrilhidrazil. Jurnal Akademika Kimia. 2014;3(3):368-74.

[3] Putri RNA. Uji Aktivitas Antioksidan Ekstrak Etanol Daun Sirsak (Annona muricata.L) dengan Metode DPPH (1,1-Diphenyl-2Picrylhidrazil) [srkipsi]. Jakarta: Universitas Islam Negeri Syarif Hidayatullah; 2012.

[4] Muthu S, Durairaj B. Evaluation of Antioxidant and Free Radical Scavenging Activity. Eur J Exp Biol. 2015;5(3):39-45.

[5] Wahyuningsih M. Potensi Pengembangan Obat Bahan Alam Indonesia untuk Penyakit Kanker. Universitas Gajah Mada; 2010.

[6] Zuhud E. Bukti Kedahsyatan Sirsak Menumpas Kanker. Jakarta: AgroMedia; 2011.

[7] Zeng L, Wu FE, Oberlies NH, McLaughlin JL, Sastrodihadjo S. Five new monotetrahydrofuran ring acetogenins from the leaves of Annona muricata. J Nat Prod. 1996;59(11):1035-42. https://doi. org/10.1021/np960447e

[8] Traggono R, Latifah F. Buku Pegangan Ilmu Pengetahuan Kosmetik. Jakarta: Pustaka Utama; 2007.

[9] Kulsum U, Saraswati R, Chandra A, Fitri K, Widyastuti FK, Studi P, et al. Optimasi waktu maserasi dan jenis pelarut terhadap kadar flavonoid pada ekstrak daun sirsak (Annona muricata L.). In: Prosiding Seminar Nasional Teknologi Industri, Lingkungan dan Infrastruktur (SENTIKUIN). Malang, Indonesia: Fakultas Teknik Universitas Tribhuwana Tunggadewi; 2019. p. 1-6.

[10] Yumas M. Formulasi sediaan krim wajah berbahan aktif ekstrak metanol biji kakao non fermentasi (Theobroma cacao L) kombinasi madu lebah. Jurnal Industri Hasil Perkebunan. 2016;11(2):75-87. https://doi.org/10.33104/jihp.v11i2.3414

[11] Yumas M, Ramlah S, Mamang. Formulasi Lulur Krim dari Bubuk Kakao Non Fermentasi dan Efek terhadap Kulit. Biopropal Industri. 2015;6(2):63-72

[12] Kurniawan DW, Wijayanto BA, Sobri I. Formulation and effectiveness of antiseptic hand gel preparations essential oils galangal (Alpinia galanga L.). Asian J Pharm Biol Res. 2012;2:245-9.

[13] Voight R. Buku Pelajaran Teknologi Farmasi. V. Soewandhi SN, editor. Yogyakarta: Gajah Mada University Press; 1995.

[14] Kuntorini EM, Astuti MD. Penentuan Aktivitas Antioksidan Ekstrak Etanol Bulbus Bawang Dayak (Eleutherine americana Merr.). Sains dan Terapan Kimia. 2014;4(1):15-22.

[15] Septiani S, Wathoni N, Mita SR. Formulasi Sediaan Masker Gel Antioksidan dari Ekstrak Etanol Biji Melinjo (Gnetum gnemon Linn.). Students e-Journal. 2012;1(1):39.

[16] Departemen Kesehatan RI. Parameter Standar Umum Ekstrak Tumbuhan Obat. Jakarta: Direktorat Jendral Pengawasan Obat dan Makanan; 2000.

[17] Aminah A, Maryam S, Baits M, Kalsum U. Perbandingan aktivitas antioksidan ekstrak etanol daun sirsak (Annona muricata L.) berdasarkan tempat tumbuh dengan metode peredaman DPPH. J Fitofarmaka Indones. 2016;3(1):146-50. https://doi.org/10.33096/ jffi.v3i1.175

[18] Standar Nasional Indonesia. Sediaan Tabir Surya SNI 16-4399-1996. Jakarta: Bandar Standarisasi Nasional; 1996.

[19] Oktaviasari L, Zulkarnain AK, Mada UG. Formulasi dan Uji Stabilitas Fisik Sediaan Lotion O/W Pati Kentang (Solanum tuberosum L.) serta Aktivitasnya sebagai Tabir Surya. Maj Farm. 2017;13(1):9-27.

[20] Dewi R, Anwar E, S YK. Uji Stabilitas Fisik Formula Krim yang Mengandung Ekstrak Kacang Kedelai (Glycine max). Pharm Sci Res. 2014;1(3):194-208. https://doi.org/10.7454/psr.v1i3.3484

[21] Garg AD, Anggarwal SG, Sigla AK. Spreading of Semisolid Formulation An Update. Pharm Technol. 2002;26(9):84-105. 
[22] Simangunsong FMP, Sri M, Hartiati A. Evaluasi Karakteristik Krim Ekstrak Kunyit (Curcuma domestica Val.) pada Berbagai Formulasi. Jurnal Rekayasa dan Manajemen Agroindustri. 2018;6(1):11-21. https://doi.org/10.24843/JRMA.2018.v06.i01.p02

[23] Hasibuan RK, Fahrurroji A, Untari EK. Formulasi dan Uji Sifat Fisikokimia Sediaan Losio dengan Berbagai Variasi konsentrasi Vitamin E [internet]. 2014 [diakses Agustus 2019]. Available from: https://www.e-jurnal.com/2015/05/formulasi-dan-uji-sifatfisikokimia.html

[24] Sumantri I, Hermawan G, Laksono H. Ekstraksi daun sirsak (Annona muricata L) menggunakan pelarut etanol. J Momentum UNWAHAS. 2014;10(1):34-7
[25] Hilwiyah A, Lukiati B, Nugrahaningsih. Skrining fitokimia dan uji aktivitas antioksidan serta kadar total fenol- flavonoid ekstrak etanol murbei (Morus alba L.) [internet]. Universitas Malang. 2015 [diakses Agustus 2019]. Available from: http://jurnal-online.um.ac.id/data/ artikel/artikel28E5B5F81EB05F5AD9931E68B5E513D4.pdf

[26] Djajadisastra J, Amin J. Uji Stabilitas Fisik dan Aktivitas Antioksidan Formula Krim yang Mengandung Ekstrak Kulit Buah Delima. Pharm Sci Res. 2014;9(2):75-86. https://doi.org/10.7454/psr.v9i2.3354 